$\xi=$

\title{
Grammar Peculiarities of Scientific and Technical Translation in Construction Sphere
}

\author{
Anna Ageicheva ${ }^{1}$, Yuliia Hunchenko ${ }^{2 *}$ \\ ${ }^{1}$ Poltava National Technical Yuri Kondratyuk University, Ukraine \\ ${ }^{2}$ Poltava National Technical Yuri Kondratyuk University, Ukraine \\ *Corresponding author E-mail: yuliyagunchenko@gmail.com
}

\begin{abstract}
Constant progress in the world construction sphere which includes innovation technologies implementation and intense business development can be observed during the recent years. All these result in the widening construction concept framework, leading to enrichment of English construction terminological system, which in turn causes huge linguists' interest to terminology, as well as intensifies research in scientific and technical translation sphere.

Construction terminology occupies a special place among other terminologies due to specificity of the human activity sphere it supplies. In the context of construction terminology the domain specific terminologies are marked out, among them the terminologies of building machinery, construction materials, mathematics, physics, chemistry, electrical engineering, town-planning, ecology, etc. Diversified study in the field of modern English construction terminology and special aspects of its translation contributes to identification of its formation regularity, functioning, systematization, and helps to predict the main tendencies of its further development. This is what determines the field of our research.
\end{abstract}

Keywords: construction terminology, grammatical difficulties, term, translation, translation difficulties.

\section{Introduction}

The issue of scientific and technical texts translation in construction sphere difficulties has acquired particular topicality for the recent two years due to considerable growth in the amount of specialized texts to be translated. In the context of Ukraine's integration into the EU, the flow of documents subject to English Ukrainian bilingual translation (international contracts, research papers to be published in the editions included into the world scientometrical databases, patents, state standards, technical documentations for household, office and industrial equipment, drugs, etc.) has become huge. Professional translators have to perform large amounts of work within the shortest possible terms. Therefore, the authors set themselves the task to help translators in rendering the most problematic aspects of English grammar.

Though the problem has only acquired its topical nature for the latest two years, still a number of scholars in Ukraine took the challenge of the translational difficulties problem and contributed to its solving. Most of the researchers are mainly concentrated on the lexical (particularly terminology) difficulties, but the grammatical aspects were also described and studied by the prominent philologists of Ukraine, such as V.I. Karaban [5], G.E. Miram [9], A.Ya. Kovalenko [6], K.O. Ryabova [12], Ya.A. Kostin [7], I.V. Onushkanych [10], O.M. Bilous [2], M.I. Zymomrya [4], A.O. Kulchitska [8], N.P. Bidnenko [1]. An outstanding Belarusian linguist and translator A.L. Pumpyanskiy [11, p.157] has contributed a lot to help professionals and students overcome difficulties of scientific and technical translation, including grammatical ones. A.Ya. Kovalenko [6, p.78] emphasized the following features of the English specialized texts: 1) very long and complicated sen- tences including a number of coordinate and subordinate clauses; 2) multi-component attributive word combinations; 3) attributes formed by means of combining whole syntactic groups; 4) specific syntactic structures, participial and infinitive constructions, passive constructions; 5) omission of certain functional words (articles, auxiliary verbs), particularly in tables, diagrams, specifications. According to K.O. Ryabova [12, p.152], one more difficulty at translation lies in misunderstanding of the context, a communication gap, caused by cumbersomeness of the original's syntactic structures. However, N.P. Bidnenko [1, p.54] says the opposite: "Clarity is an important part of scientific style. It can be achieved by using simple language choices in scientific writings as these help improve the ease with which scientists will be able to understand. Sentences are not long and don't contain too many clauses. If a sentence is too long, it is divided into several smaller ones." This contradiction in the above scholars' opinions, as the authors of the present study understand it, can be possibly explained by the fact that in the recent years the requirements to the scientific and technical papers style have considerably changed towards simplification. It can be noticed when comparing the style of articles written in 1990-s with those of the present day: the latter are written in a much clearer language and sentences have a stricter structure.

\section{Problem Search}

The aim of the present study is to determine the most significant grammatical difficulties that occur in the process of translating from English into Ukrainian and vice versa and to suggest the efficient ways of their mastering. 
The tradition of differentiating complicated cases of translation between grammar and lexical difficulties is relative enough, since in every language grammar is closely connected with vocabulary and the way of translating grammar forms and structures often depends upon their lexical semantics. One and the same grammar feature depending on its particular lexical meaning can be translated in different ways.

However, there exist certain general regularities of grammar forms and structures correlation and equivalence in the source and target languages. Therefore, description of the said correlations, oriented towards translation, seems not only reasonable, but necessary to obtain sufficiently clear ideas of the tools and opportunities being at the translator's disposal to provide the adequate translation of the source language's grammar phenomena.

The language of scientific and technical texts considerably differs from that of the conversational speech or fiction by certain lexical, grammar and stylistic features. If lexical differences are evident even to a non-professional (and it is primarily a great deal of specialized vocabulary and terms), those of grammar are by far less expressed though no less diverse.

It should be underlined that the present study does not only refer to inventory differences, i.e. those in the syntactic constructions composition or in morphological forms, but it concerns differences in grammar elements functioning. One of the most visible grammar features of scientific and technical texts is a huge number of various expanded (primarily complex) sentences, used to preserve typical for scientific presentation of logical relations between subjects, actions, events and facts.

There are also grammar differences between the two texts written in two different languages caused by peculiarities of a language's grammar structure, norms and traditions of the written scientific presentation. Thus, in English-written specialized texts, Passive Voice forms, impersonal verbs, Participial clauses and specific syntactic constructions, personal pronouns in the first person singular and monomial infinitive and nominative constructions occur much more frequently than in the analogous Ukrainian texts.

Thus, in Ukrainian both definite and indefinite articles are absent, whereas in English they are not only used as certain attributes, but they indicate the features of the information distribution within the English sentence. The mandatory requirement to the adequate translation is correct analysis of the English sentence's grammar structure, correct determination of translation difficulties and constructing sentences in the translation text in accordance with the language norms and genre of the translation.

It is self-evident that the translator should possess good knowledge of the both (source and target) languages' grammar features, of the translation theory basics in general and the scientific and technical translation features in particular, as well as knowledge of their translation equivalents in the grammar and lexicology fields, translational transformations, means of translating various language and speech phenomena. It all constitutes part of the general translator's competence, which is certainly much broader than that described here.

\subsection{Particular Grammatical Difficulties of Translation.}

The most important aspect of the translator's activity is knowledge of the translated subject, as a translator should be proficient enough in the branch of science which the text to be translated belongs to. While translating, one should properly understand the meaning of sentences, sense relations between the sentences as well as the meaning of metatextual elements participating in the text structure.

The first group (the largest number) of grammar problems is connected with misunderstanding of the syntactic structure and morphological composition of the sentence translated as language elements which are the direct information carriers on the subject matter. Both languages, English and Ukrainian, are known to belong not only to different branches of the Indo-European language family (the former belongs to German, and the latter to Slavonic branch), but, moreover, they belong to different language structure types: the former is mostly analytical language, where grammar relations in the sentence are expressed by means of free grammar morphemes, while the latter is a flexional language, where grammatical meaning and relations in the sentence are expressed by means of bound grammar morphemes, i.e. flexions. It is differences in the very structures of the two languages, in the set of their grammar categories, forms and constructions that constitute the first large group of grammar difficulties in translation.

For instance, Ukrainian does not contain articles, Gerund, verb tense forms belonging to the Continuous and Perfect groups, Complex Subject and Complex Object infinitive constructions, whereas in English there no category of noun and adjective gender, case inflection, etc. Certain differences exist in the structure of an English sentence, where the Subject group can quite frequently be located after the Predicate group. The order of words in English is significantly more strictly fixed which can require the sentence restructuring at translation.

The second group of grammar translation difficulties is connected with the different content volume of analogous forms and constructions in the two languages. Thus, the present tense form of the verb-predicate in Ukrainian corresponds by its meaning to the respective forms of Present Indefinite, Present Continuous and partly Present Perfect in English, and the genitive case form of the Ukrainian noun can correspond by its grammar meaning to the preposition-and-noun construction " $o f+N$ " in English or to the noun common case form in the preposition to other noun.

The third group of grammar translation difficulties includes the grammar features of the original text's language possessing functional characteristics different from the respective grammar features in the target language. For example, singular and plural noun forms are present in the both languages, but some particular noun forms can disagree with each other (e.g. English "evidence" is only used in singular, but it can be translated both in singular and in plural).

The fourth group of grammar translation difficulties comprises grammar features possessing different frequency characteristics in English and Ukrainian scientific and technical literature. For example, in the former language the frequency of the verbpredicate's Passive Voice forms is significantly higher than in the latter one, therefore such forms have to be often replaced with the Active Voice forms in the process of translation. The above difficulties are caused by discrepancies in the language stylistic norms of both the source and target languages.

The fifth group of grammar translation difficulties is presented for the beginners by grammar homonyms, formally identical grammar forms or constructions performing different grammar functions (for example, verb "to $d o$ " can be used as an auxiliary verb in negative and interrogative sentences, as a representative of the previous verb and as a notional verb).

The sixth group of grammar translation difficulties is connected with peculiarities of expressing the sentence parts in the both languages, primarily that of the subject and the predicate. For example, English possesses the so-called "formal subject" and "formal object" that are impossible in the Ukrainian sentence's structure. Only a small part of English and Ukrainian expressions has identical syntactic structure and the order of components; it is the only case when English expressions can be translated by the respective Ukrainian expressions without any grammar transformations.

This way of translation is called "literal" or "word-by-word" translation. It should be differentiated from the grammatically literal translation which is the word-by-word translation of the grammar form or the syntactic construction, thus violating grammar norms of the target language and / or genre-style standards of scientific and technical literature.

Grammatical literalism, according to K.O. Ryabova [12, p.152], not only causes violation of the target language's norms, but it is responsible for various meaning distortions of the original. For example, if the following sentence: "A new element will be discovered sooner or later" is translated grammatically ad litteram, the result will be: "Новий елемент буде відкрито раніше чи niзніше". In this case, a violation of the adverbial degrees of com- 
parison's functioning in Ukrainian is observed. In the analogous cases, the form of the positive, but not the comparative, degree should be used ("рано чи пізно").

The following literal translation is distorting the original's meaning and violates certain grammar norms of the Ukrainian language, according to which the participial construction cannot be introduced by a conjunction and the anaphoric possessive pronoun must have the "свiü" form, but not that of "üого": "While taking part in the discussion he advanced his famous theory." - "Коли, беручи участь у дискусії, він висунув його відому теорію" (The correct variant is: "Саме під час иієї дискусії він висунув свою знану тепер теорію".

The literal translation is performed successively from the first word in the sentence to the last one. It does not exclude removing articles and certain lexical transformations, if as a result of their using the structure and the parts order of the sentence translated do not change. E.g.: "This is the phenomenon of diffraction." - "Цеявище дифракиіï." - "It is one of the basic questions of any sciепсе." - "Це є одним з головних питань будь-якої науки." It is particularly to avoid the inadequate literal translation ("grammatical literalism"), the translator should apply translational grammatical transformations due to which a literal translation is adapted to the norms of the target language and becomes adequate.

Grammatical transformations are caused by many factors. In particular, the reasons for these transformations are: 1) Differences in the means of information rendering in English and Ukrainian sentences: notions rendered by lexical means in one language are expressed by grammatical means in another. For example: precedence of one action to another in the past is expressed in English by the Past Perfect form of the verb-predicate, whereas in Ukrainian it is rendered by words or word combinations ("раніше", “"перед ичим", “до того”, еtc.).

2) Lack of certain grammatical features in one of the languages, including forms and constructions. Thus, in Ukrainian, articles, Gerundial form of the verb, formal object ("it") are absent, while in English there no gender forms of nouns and adjectives, caseforms of numerals, etc. 3) Optionality of grammatical information expressing in one of the languages (for example, in Ukrainian, the information on the fact that the action is taking place at the moment of speaking, is not grammatically expressed, whereas in English it is realized through the Present Continuous tense form).

4) Differences in presenting the content of the sentence by a surface structure (for example, in English, complex information in the Object can be expressed by a complex object, i.e. Objective Infinitive). 5) Peculiarities of combinatorial ability and functioning of words in word combinations and sentences (for example, due to combinability features of the adjective "administrative", the word combination "administrative efficiency" cannot be translated as "адміністративна ефективність", but it should be rendered as "ефективне управління".

Translational grammatical transformation is thought of as changes in the grammatical features of a word, a word combination or a sentence in the translation. A distinction is made between the five basic types of grammatical transformations: permutation (reordering), substitution (replacement), addition, omission and a complex transformation.

Permutation is a grammatical transformation causing changes in the word order in a word combination or in a sentence. For example, in the Ukrainian sentence the connective word "однак" is usually placed in the beginning of the sentence, whereas in the English sentence its equivalent "however" can be placed in the middle and in the end of the sentence; an attributive noun in English can be placed into the preposition before the main noun ("theory construction"), while in Ukrainian an attributive noun is usually placed after the main noun ("побудова теорії").

Permutations are frequently accompanied by another grammatical transformation, namely, substitution, which causes changes in the grammatical features of word forms (e.g. instead of the singular form, the plural form is used in the translation), parts of speech (e.g. infinitive is transformed into noun in the translation), parts of the sentence (e.g. the object is transformed into the subject at translation), sentence (e.g. a simple sentence is transformed into a complex one and vice versa at translation). "Much work has been done on the problem. - 3 иієї проблеми написано багато праџь. - Brakes must be applied to stop a car.- Щоб зупинити автомобіль, необхідно застосувати гальма.- This year has seen many great discoveries. - У иььму роияі відбулось багато великих відкриттів."

Additionally, substitutions of words with word combinations, word combinations with sentences, a series of sentences with one complex sentence and vice versa can occur in the process of translation. For example: "I shall discuss those points in greater detail.- Я розгляну иі положення докладніше. - This is true also for the language used in the scientific area of culture. - Це вірно також $i$ для мови, яка використовується в науковому дослідженні культури. - This is what makes them meaningful.Саме ие й робить їх значущими.- Einstein, too, confessed the same admiration for ancient geometry. - Ейнштейн також зізнавався, щуо й він теж був захоплений геометрією древніх. The conference was a veritable summit meeting. Only Bohr was conspicuously absent - Ця конференція була справжньою зустріччю у верхах, $і$ лише Бора там явно бракувало.

Kepler set out to unify the classical picture of the world, one which was split into celestial and terrestrial regions, though the concept of a universal physical force, but when this problem did not yield to physical analysis, he readily returned to the devices of a unifying image, namely, the central sun ruling the world, and of a unifying principle, that of all-pervading mathematical harmonies. - Кеплер намагався зробити єдиною класичну картину світу, який до иьвого був розділений на небесну $і$ земну сфери. Для иього він використав поняття загальної фізичної сили. Та коли ия проблема не піддалася фізичному аналізу, він невдовзі повернувся до механізмів об'єднуючого образу, в иентрі якого - соние, що панує над всім світом, та об'єднуючого принщипу всюдисущих математичних гармоній. "'

Addition is a grammatical transformation due to which the amount of words, word forms or parts of the sentence in the translation grows. For example, in the following translations the word forms "applications" and "introduces" are translated by means of combining two words: "There are many different applications of this material. - Цей матеріал застосовується у багатьох різних галузях. The mutual effect introduces a complex change. Перехресний вплив призводить до появи комплексних поправок." Addition is used at translating nouns (e.g. "intricacies" - "складні проблеми та заплутані питання"), adjectives (e.g. "recurrent" - "шо періодично повторюється"), verbs (e.g. "to solve" - "знаходити вирішення"), adverbs (e.g. "theoretically" - "у теоретичному плані"), nominalized adjectives (е.g. "the intracellular" - "внутрішньоклітинне середовище"), words belonging to other parts of speech and word combinations (e.g. "data rates" - “ивидкість передачі даних"). Omission is a grammatical transformation when a certain language element is removed in the translation (it often occurs to be a pleonastical word, word form, member of the sentence or part of the sentence). For example: "The explosion was terrible while it lasted. - Вибух був жахливий. This is a very difficult problem to tackle. - Це дуже складна проблема." A complex grammatical transformation includes two or more simple grammatical transformations, for example, when in the process of translation permutation and addition are performed simultaneously (e.g. "The motor was found to stop within 2 seconds. - Виявилося, що електромотор зупиняється протягом двох секунд.").

Since grammar is closely connected with vocabulary, most of the translational transformations possess a mixed nature, i.e. simultaneous lexical and grammatical changes are taking place at translation. This type of lexico-grammatical transformations is called mixed transformations and includes all the above mentioned grammatical transformations as well as various lexical transformations (generalization, specification, contextual substitution, etc.). For example, the following translation includes replacement of Gerund with a noun and the singular form of the noun " $r e$ search" with the plural form "дослідження", as well as lexical 
transformations: contextual substitution of the adverb "heavily" with "чироко", preposition "in" with preposition " $р и$ " and the pronoun " $P$ " with the pronoun " $m u$ ": "In identifying these features / relied heavily on previous research. - При визначенні цих ознак ми широко використовували попередні дослідження."

\section{Conclusion}

Skills and abilities of making translational transformations constitute a significant component of a translator's competence, therefore considerable attention should be paid to their training and correct application. Translational transformations should be aimed at adequate rendering the meaning of the original's information, taking into account the target language's norms. Transformations are obligatory at translating the English grammar features absent in Ukrainian. Analysis of methods for translating various grammatical forms and constructions is performed within the context of a sentence, since, on the one hand, it is the sentence which is the language unit which lends itself to systemic study, and on the other hand, the absolute majority of grammatical features are expressed in it. Only in the cases, when it is inevitable, translation is considered on the material of sentences combination.

\section{References}

[1] Osypova I.I., Derzhavna sluzhba statystyky Ukrainy. Samootsinka domohospodarstvamy Ukrainy rivnia svoikh dokhodiv. Statystychnyi zbirnyk, 2017, pp.9-12, available online: http://ukrstat.org/uk/druk/publicat/Arhiv_u/17/Arch_sdrd_zb.htm, last visit: 20.02 .2018 .

[2] Beer A., Thredgold Ch., Horne S. \& Charlier J., Public housing stock transfer - impacts and implications for local government: final report (2014), available online: http://apo.org.au/node/66345//, last visit: 28.02.2018, doi: 10.4225/50/57D892FC27BBC.

[3] Zayats T. \& Yanevych N., Evaluating of effectiveness of social investments financed from the budget of territorial communities, The Economic Annals-XXI, № 5-6(1), 2013, pp.6-59, doi: https://doi.org/10.21003/ea.

[4] Trusova N. \& Klimenko, P., Building of socio-economic politics in the context of regional safety, Economic Annals-XXI. Vol. 157, № 3-4(1), 2016, pp. 38-40, doi: http://dx.doi.org/10.21003/ea.V157-0011.

[5] Tinkova E. \& Tinkov S., Production potential development and quality of life of the population indicators modeling, Economic Annals-XXI, Vol. 157, № 3-4(1), 2016, pp.47-49, doi: http://dx.doi.org/10.21003/ea.V157-0014.

[6] Plagerson S. Can social protection address both poverty and inequality in principle and practice? Global Social Policy, 2016, available online:

http://gsp.sagepub.com/content/early/2016/01/02/14680181156225 21, last visit: 20.02 .2018 . abstract doi: $10.1177 / 1468018115622521$

[7] Ilyash O., The principles of state regulation in the sphere of socioeconomic security of Ukraine, The Economic Annals-XXI, № 78(1), 2014, pp. 24-28.

[8] Komelina O. \& Fursova N., Evaluation of social security: systemic and synergetic approach, The Economic Annals-XXI, № 7-8(1), 2014, pp.12-15.

[9] Kharabara, V., Analysis of mortgage lending in banks in Ukraine. Baltic Journal of Economic Studies, Vol. 3, №3, 2017, pp.59-63, doi: $10.30525 / 2256-0742$.

[10] Zavora T. \& Chepurny O., Forming the diagnostics methods of social security condition in a region, Economics \& Sociology, Vol. 7 , № 1, 2014, pp. 228-248, doi: 10.14254/2071-789X.2014/7-1/20.

[11] Onyshchenko V.O., Zavora T.M. \& Chepurnyi O.V., Sotsialna bezpeka rehionu: teoretychni ta prykladni aspekty: monohrafiia, Poltava: PoltNTU, 2015, 274 p.

[12] Onyshchenko V.O., Zavora T.M., Orhanizatsiino-ekonomichni zasady suchasnoi zhytlovoi polityky: rehionalnyi vymir: monohrafiia, Poltava: PoltNTU, 2012, 248 p.

[13] Xu Y., Mandatory savings, credit access and home ownership: The case of the housing provident fund, Urban Studies, Vol. 54, №15, 2017 pp.3446-3463, doi: 10.1177/0042098016676158.

[14] Paulo Nascimento Neto, Tomás Antonio Moreira, \& Zulma Das Graças Lucena Schussel, Housing Policy. A Critical Analysis on the Brazilian Experience. Mobility and Competitiveness, Vol 5, № 3 3, 2012, pp.65-77.

[15] Osnovni pokaznyky sotsialno-ekonomichnoho rozvytku Ukrainy, available online: http://www.ukrstat.gov.ua, last visit: 28.01.2018

[16] Kalashnyk L. V., Statystychnyi shchorichnyk Poltavskoi oblasti za 2016 rik, Poltavskyi literator, 2017, pp.80-86.

[17] Varnaliy Z., Onishchenko S. \& Masliy A., Threat prevention mechanisms of Ukraine's economic security, Economic AnnalsXXI, Vol. 159, №5-6, 2016, pp. 20-24, doi: http://dx.doi.org/10.21003/ea.V159-04

[18] Thai Pham Huu Hong, Influence of Government spending on the house prices in Vietnam, Economic Annals-XXI, Vol. 162, № 11 12, 2016, pp.53-55, doi: https://doi.org/10.21003/ea.V162-11.

[19] Ferrero A., House price booms, current account deficits, and low interest rates. Journal of Money, Credit and Banking, 47(S1), (2015). pp. 261-293, doi: https://doi.org/10.1111/jmcb.12202

[20] Johansen S., \& Juselius K., Maximum likelihood estimation and inference on cointegration - with applications to the demand for money, Oxford Bulletin of Economics and statistics, №52(2), 1990, pp.169-210, doi: https://doi.org/10.1111/j.14680084.1990.mp52002003.x. 